\title{
CISTINĖS FIBROZE்S KOMPLIKACIJOS IR JŲ GYDYMAS
}

\author{
Paulius Bajerčius \\ Vilniaus universiteto Medicinos fakultetas
}

Raktažodžiai: cistinè fibrozė, komplikacijos, gydymas.

\section{Santrauka}

Cistinè fibrozė yra genetinè liga, sukelta CFTR geno 7 chromosomoje. Ligos perdavimas vyksta autosominiurecesyviniu būdu. Žmonès, turintys vieną mutavusią kopiją, dažniausiai būna sveiki. Sergantys cistine fibroze išskiria klampesni sekretą, kuris sukelia obstrukcinius patologinius pokyčius ịvairiuose organuose. Šie pokyčiai veda prie sunkių komplikacijų, kurios ženkliai blogina pacientų gyvenimo kokybę ir kelia didelio mirtingumo riziką. Dèl sisteminio poveikio, cistinès fibrozès gydymas turi būti daugiadisciplininio pobūdžio, todèl svarbu moketi diagnozuoti ir įvertinti organizmo pažeidimus, kuriuos sukelia ši liga.

Tyrimo tikslas - apžvelgti cistinès fibrozės komplikacijas bei jos gydymo metodus.

Tyrimo medžiaga ir metodai. Literatūros buvo ieškota Pubmed duomenų bazeje. Paieškos metu naudoti raktiniai žodžiai ir jų kombinacijos: cistinè fibrozé, komplikacijos, gydymas, paveiktos sistemos. Atlikta nuosekli 150 straipsnių patikra ir pašalinti besidubliuojantys ar tyrimo tikslo neatitinkantys staipsniai. Atrinkti ir išanalizuoti 49 tyrimui tinkami viso teksto straipsniai arba jų santraukos. Rezultatai. Cistinè fibrozè neišgydoma, todèl orientuojamasi ị komplikacijų prevenciją ir gydymą. Dažniausiai pažeidžiamos kvėpavimo, virškinimo, renalinè ir endokrinine sistemos. Pagrindinès komplikacijos augimo sutrikimai, kasos nepakankamumas, malabsorbcija, cukrinis diabetas ir ịvairi kepenų patologija dèl kasos ir tulžies latakų pažeidimų, dažnos plaučių komplikacijos ir, galiausiai, kvẻpavimo nepakankamumas dèl patologinių pokyčių kvẻpavimo takuose. Kvẻpavimo nepakankamumas gydomas plaučių ventiliacija. Terminalinėse komplikacijų stadijose gydymas paremtas organų transplantacijomis.

Išvados. Nepaisant gydymo, organų pažaida progresuoja ir daugeliui pacientų galutinèse ligos stadijose indikuotina organų transplantacija. Vis dèlto, pritaikius adekvatų gydymą, įmanoma ženkliai pailginti paciento gyven- imo trukmę. Cistinès fibrozės komplikacijų gydymas turi teigiamos įtakos kitų komplikacijų prevencijai.

\section{Ivadas}

Cistinè fibrozė - tai genetinè liga, pasireiškianti daugelio organų (plaučių, kasos, kepenų, inkstų ir kt.) pažeidimu. Liga yra sukelta CFTR (angl. cystic fibrosis transmembrane conductance regulator) geno mutacijos 7 chromosomoje. Dèl šios mutacijos organizmo liaukos išskiria didesnio klampumo sekrecijas, kurios gali užkimšti ịvairių organų liaukas ir latakus, taip sukeldamos šių organų disfunkciją. Dažnai šie sutrikimai komplikuojasi infekcijomis [1].

Cistinè fibrozė perduodama autosominiu-recesyviniu būdu ir yra viena dažniausių genetinių ligų europinès kilmès žmonių populiacijose [2].

Dèl sisteminio poveikio, cistinè fibrozė gali pasireikšti daugeliu sunkių komplikacijų, kurių prevencija ir gydymas yra itin svarbūs, norint palaikyti kuo ilgesnę gyvenimo trukmę ir kokybę [1].

Tyrimo tikslas - apžvelgti cistinès fibrozès komplikacijas bei jos gydymo metodus.

\section{Tyrimo medžiaga ir metodai}

Literatūros buvo ieškota Pubmed duomenų bazèje. Paieškos metu naudoti raktiniai žodžiai ir jų kombinacijos: cistinè fibrozè, komplikacijos, gydymas, paveiktos sistemos. Atlikta nuosekli 150 straipsnių patikra ir pašalinti besidubliuojantys ar tyrimo tikslo neatitinkantys staipsniai. Atrinkti ir išanalizuoti 49 tyrimui tinkami viso teksto straipsniai arba jų santraukos.

\section{Tyrimo rezultatai}

Kasos nepakankamumas. Dėl kasos duktulių obstrukcijos sutirštinta sekrecija, cistinė fibrozè dažnai pasireiškia kasos nepakankamumu [1]. Sutrikus kasos funkcijoms, pacientams pasireiškia malabsorbcijos ir maldigestijos simptomai, galintys sutrikdyti augimą, kognityvines funkcijas, sukelti kitų organų pažaidą ir avitaminozes [1,3]. Ši komplikacija gali būti diagnozuota tokiais diagnostiniais testais, kaip fekalinès elastazès testas bei serumo tripsinogeno testas 
(šis testas nèra dažnas klinikinèje praktikoje) [4]. Maždaug 80-90 proc. sergančiujų cistine fibroze kasdieniame gyvenime turi vartoti egzogeninius kasos virškinimo fermentus [5]. Rekomenduojama fermentų dozė gali būti mažesnè nei 2500 lipazès vienetų kilogramui po vieno patiekalo arba mažesnè nei 4000 lipazès vienetų gramui riebalų per dieną [6].

Kasos fermentų vartojimas efektyvesnis, kartu vartojant skrandžio $\mathrm{pH}$ didinančius vaistus [7].

Pankreatitas. Apie 10 proc. sergančiųjų cistine fibroze, esant išlikusiai kasos funkcijai, suserga pankreatitu [8]. Dažniausiai ūmiu pankreatitu serga tik pacientai, kuriems nepasireiškẻ kasos nepakankamumas [9]. Pankreatito gydymas cistinès fibrozès metu toks pat, kaip pankreatito gydymas nesergant cistine fibroze - hidratacija, skausmo malšinimas, laikina dieta be riebalų. Prevencijai rekomenduojamas alkoholio ribojimas $[10,11]$.

Cukrinis diabetas. Nuo 40 iki 50 proc. cistine fibroze sergančių pacientų suserga cukriniu diabetu dèl pakitimų kasoje, Langerhanso salelèse [12]. Salelių beta ląstelès tampa disfunkciškos, o tai veda prie insulino gamybos sutrikimų ir insulinopenijos [13]. Nepaisant gydymo, cistine fibroze ir cukriniu diabetu sergančių pacientų mirtingumas išlieka aukštesnis, nei sergančiujų cistine fibroze, nesant cukrinio diabeto [14].

Cukrinis diabetas asocijuotas su susilpnejjusia plaučiu funkcija ir didesniu imlumu plaučiu infekcijoms. Kartu gali pasireikšti neuropatijos, inkstų sutrikimai, aterosklerotiniai procesai [13]. Su cistine fibroze asocijuotas cukrinis diabetas diagnozuojamas kitokiais metodais, nei kitos kilmès cukrinis diabetas. Pacientai dažnai patiria praeinančią postprandialinę hiperglikemiją, todèl gliukozès kiekio kraujyje nevalgius matavimas nėra patikimas diagnostikos metodas [13]. Glikuoto hemoglobino matavimas taip pat nèra labai patikimas metodas, kurio jautrumas siekia tik 50 proc., lyginant su gliukozès toleravimo mèginiu. Glikuoto hemoglobino rodiklis nekoreliuoja su gliukozès kiekiu kraujo plazmoje $[15,16]$. Pagrindinis rekomenduojamas su cistine fibroze susijusio cukrinio diabeto diagnostikos metodas yra oralinis gliukozès tolerancijos mėginys [17], tačiau šis metodas taip pat ne visada tikslus [18]. Su cistine fibroze asocijuojamo cukrinio diabeto gydymo tikslas yra mažinti glikemiją, gliukozės kiekị kvejpavimo takuose ir išlaikyti tinkamą plaučių funkciją. Šie tikslai pasiekiami insulino terapija [19].

Gastroezofaginio refliukso liga (GERL). 35-81 proc. suaugusiujų, sergančių cistine fibroze, kartu patiria GERL simptomus (pvz., rèmuo, deginimo pojūtis, disfagija ir dispepsija) [20]. Cistine fibroze sergančių pacientų refliuksas dažniausiai yra acidinès kilmès [21]. GERL gydyti skiriami protonų pompos inhibitoriai (pirmos eilès vaistai) bei histamino 2 receptorių antagonistai [22]. Vartojantiems šiuos vaistus kartu, pastebèta geresnè plaučių funkcija [23].

Kitas GERL gydymo metodas - laparoskopine fundoplikacija, kurios tikslas yra atkurti apatinio stemplès sfinkterio slègị, apgaubiant apatinę stemplès dalị skrandžio dugnu [24]. Vieno tyrimo duomenimis, cistine fibroze sergančių pacientų, kuriems buvo atlikta laparoskopinè fundoplikacija, sumažèjo kosulio simptomų kiekis ir dažnis bei plautinių ivvykių skaičius [25].

Augimo sutrikimas. Augimo sutrikimas yra dažna pacientų, sergančiu cistine fibroze, patologija. Dažniausiai sutrikimas pasireiškia dèl kvèpavimo funkcijos pažeidimo kartu su malabsobcija, tačiau augimo hormono sekrecijos sutrikimas yra papildomas veiksnys augimo sutrikimu patofiziologijoje. Pacientų, sergančių cistine fibroze populiacijoje, augimo hormono sekrecijos sutrikimų dažnis 200 kartų didesnis, nei bendroje populiacijoje [26].

Augimo sutrikimu gydymas yra paremtas tinkamos plaučiu funkcijos palaikymu, malabsorbcijos gydymu bei tinkama, daug kalorijų (kasdienis kalorijų vartojimas turètų būti didesnis, nei sveiko žmogaus) bei riebalų turinčia dieta su vitaminų papildais ir, jei reikia, egzogeninių kasos fermentų vartojimu $[27,28]$.

Manoma, kad augimo hormono terapija galètų būti papildomas augimo sutrikimų gydymo metodas, tačiau dar trūksta pakankamai duomenų šio metodo efektyvumui ịvertinti [28].

Kepenų patologija. Pacientai, sergantys cistine fibroze, yra labiau linkę i ịvairias kepenų ligas, ypač per pirmuosius 10 gyvenimo metǔ. Šis polinkis mažèja antrajame gyvenimo dešimtmetyje [29]. Iki 41 proc. vaikų iki 12 metu nustatomi kepenų transaminazių pokyčiai [30]. Nuo 5 iki 10 proc. pacientų per pirmuosius 10 gyvenimo metų suserga kepenų ciroze, kuri progresuoja i portinę hipertenziją ir jos komplikacijas (stemplès ir skrandžio varicelinị kraujavimą) [29].

Sergama tokiomis ligomis, kaip židininè biliarinè cirozè, cholelitiazè, periportalinè fibrozè, kepenų cirozé, portinè hipertenzija bei varicelinis kraujavimas [1].

Kepenų patologijai diagnozuoti reikalingas bendro kraujo tyrimų, biocheminių kepenų fermentų tyrimų ir radiologinių metodų (tokių kaip kepenų ultragarsinis tyrimas, pilvo kompiuterine tomografija ir magnetinis rezonansas) derinys. Auksinis standartas įvertinti hepatocitų pažeidimo laipsnị yra biopsija [31].

Cholestazinès kepenų patologijos farmakologinių gydymo metodų nėra daug. Šiuo metu vienintelis skiriamas vaistas yra ursodeoksicholio rūgštis, kuri keičia tulžies turini ir viskozitetą, taip gerindama biliarinę sekreciją bei stabdydama kepenų patologijos progresavimą [31]. Kitas kepenų terminalinių stadijų gydymo metodas - kepenų transplantacija. Nors cistine fibroze sergantys pacientai pasižymi blogesniu 5 metų išgyvenamumu po transplantacijos, palyginti 
su transplanto recipientais, kurie neserga cistine fibroze, ju išgyvenamumas daug didesnis nei tų, kuriems transplantacija neatlikta [32]. Kepenų transplantacija neturi efekto paciento plaučių funkcijai [33].

Indikacijos kepenų transplantacijai - diagnozuota kepenų cirozè su tokiomis komplikacijomis, kaip gelta, ascitas, encefalopatija, vitaminui $\mathrm{K}$ atspari koagulopatija, hipoalbuminemija, hepatopulmoninis sindromas arba portopulmoninė hipertenzija, sunkus mitybos sutrikimas, ženklus gyvenimo kokybės sumažẻjimas bei ženkliai trinkanti plaučių funkcija [31].

Plaučių patologija. Plaučių patologija cistinès fibrozès metu yra viena iš sunkiausių ir dažniausių komplikacijų ir mirties priežastis 66 proc. sergančiujų [34]. Dẻl pažeistų plaučiu ir infekcijų, raida gali papildomai komplikuotis tokiomis būklèmis, kaip pneumotoraksas ir hemoptizè [1].

Pneumotoraksas - tai oras pleuros ertmėje. Simptomai pasireiškia kaip krūtinès skausmas ir dusulys. Skausmas yra pleurinio tipo - aštrus ir stiprus, plintantis ị tos pačios pusés petị [35]. Vieno tyrimo duomenimis, 1 iš 167 pacientų, sergančių cistine fibroze, patiria spontatini pneumotoraksą per metus, 72,4 proc. pneumotoraksų ištiko pacientus, vyresnius nei 18 metu [36]. Net 50-90 proc. pacientų patiria kartotini pneumotoraksą [37].

Pneumotorakso rizikos veiksniai - kvejpavimo takų infekcijos (Pseudomonas aeruginosa, Burkholderia cepacia ir Aspergillus), FEV $1<30$ proc. normalios vertès, maitinimas per gastrostomą, kasos nepakankamumas ir didelè hemoptizė (36]. Vaistų inhaliacijos (tobramicino ir dornazès-alfa) gali didinti pneumotorakso riziką dèl ūmaus FEV1 sumažèjimo po inhaliacijos [38]. Cistinè fibrozė didina pneumotorakso riziką tiek dèl struktūrinių kvẻpavimo takų pokyčių, tiek dèl oro patekimo dinamikos pokyčių. Endobronchinė obstrukcija ir uždegimas dèl padidejjusio klampumo sekrecijų ir tokių uždegiminių ląstelių, kaip makrofagai, akumuliacijos gali sukelti oro nepraeinamumą ir padidejusị slègị alveolių audinyje, todèl gali plyšti plaučių parenchima $[39,40]$.

Pneumotoraksas gali būti diagnozuojamas krūtinès ląstos radiograma, tačiau krūtinès kompiuterinès tomografijos tyrimas yra jautresnis [41]. Pneumotoraksas gydomas krūtinės intubacija ir chirurgine pleurodeze (jei būklè kartotinè) [42]. Gydymui atsparus ir toliau pasikartojantis pneumotoraksas gydomas plaučių transplantacija [39]. Po terapinès intervencijos rekomenduojama fizioterapija [43].

Hemoptizè. Hemoptizè - atsikosẻjimas krauju. Tai dažnas $(9,1 \%)$ cistine fibroze sergančiu žmonių simptomas [44]. Nors dažniausiai atkosèto kraujo nèra daug, galimi masyvios hemoptizès atvejai, kada nukraujuojama daugiau nei $240 \mathrm{ml}$ per parą arba $100 \mathrm{ml}$ kas parą per kelias paras [36]. Masyvią hemoptizę patiria 1 iš 115 cistine fibroze sergančiu pacientų per metus [45]. Masyvios hemoptizès diagnozuojamos pagal klinikinius požymius, krūtinès ląstos rentgenogramos tyrimą, krūtinès kompiuterinès tomografijos tyrimą, bei bronchoskopiją, jei kiti tyrimai nepakankamai informatyvūs [46].

Pagrindinis gydymo tikslas yra sustabdyti kraujavimą [47]. Masyviai hemoptizei gydyti gali būti atliekama bronchinès arterijos embolizacija [46]. Pirminis embolizacijos veiksmingumas - 95 procentai [48]. Jei embolizacija nesèkminga arba būklè kartojasi, galimas chirurginis gydymas - plaučio rezekcija [46].

Kvėpavimo nepakankamumas. Dėl progresuojančio plaučių funkcijos sutrikimo sergant cistine fibroze, kvėpavimo nepakankamumas yra dažna terminalinè komplikacija [1]. Šios būklès gydymas paremtas simptomų (dispnejja ir skausmas) šalinimu, infekcijų kvejpavimo takuose gydymu antibiotikoterapija, obstrukcijos plaučiuose gydymu (bronchodilatatoriai, retai atliekama terapinè bronchoskopija), malabsorbcijos gydymu bei neinvazine ventiliacija (vienas pagrindinių kvėpavimo nepakankamumo gydymo metodų) $[1,49]$. Galutinių stadijų kvépavimo nepakankamumo gydymo metodas - plaučių transplantacija. Transplantacija indikuotina, kai numatomas 5 metų išgyvenamumas yra mažiau nei 50 proc., FEV1 $<30$ proc. normalios vertès, greitai mažejjanti FEV1 vertè nepaisant tinkamo gydymo, 6 minučių $400 \mathrm{~m}$ atstumo ejjimo trukmè, plautinè hipertenzija be hipoksemijos paūmèjimo, klinikos progresavimas, pasireiškiantis didesniu klinikos paūmèjimų dažniu bei gydymo neefektyvumu. Visos transplantacijos cistinès fibrozès atveju turètų būti abiejų plaučių, nes vienas paliktas pažeistas plautis gali būti infekcijos šaltinis ir lemti galimas kvejpavimo nepakankamumo komplikacijas. Nors plaučių transplantacija neišgydo cistinès fibrozès, ji pailgina gyvenimą ir efektyviai palengvina simptomus [1].

\section{Išvados}

1. Dažniausios cistinès fibrozės komplikacijos pasireiškia kvėpavimo, virškinimo ir endokrininėje sistemose.

2. Sunkiausios komplikacijos - kasos nepakankamumas, pankreatitas, cukrinis diabetas, kepenų cirozè, pneumotoraksas, masyvi hemoptizè ir kvèpavimo nepakankamumas (sergančiųjų cistine fibroze dažniausia mirties priežastis). Pagrindinis kvėpavimo nepakankamumo gydymo metodas - plaučiu ventiliacija.

3. Daugelis komplikaciju gali būti tinkamai gydomos arba jų klinikinè išraiška palengvinama tokiais metodais, kaip egzogeninių virškinimo fermentų vartojimas ir alkoholio nevartojimas.

4. Cukrinio diabeto dèl kasos pažeidimo gydymas -insulino terapija.

5. Komplikacijų gydymas daugiaveiksnis, tačiau ga- 
lutinėse ligos stadijose rekomenduojama pažeisto organo transplantacija.

6. Cistinès fibrozės komplikacijų gydymas turi teigiamos itakos kitų komplikacijų prevencijai.

7. Šiuo metu trūksta duomenų augimo sutrikimų gydymo augimo hormono terapija efektyvumui nustatyti.

\section{Literatūra}

1. Yu E, Sharma S. Cystic Fibrosis. StatPearls Publishing 2021. http://www.ncbi.nlm.nih.gov/books/NBK493206/

2. Davies JC, Alton EWFW, Bush A. Cystic fibrosis. BMJ 2007;335(7632):1255-9.

https://doi.org/10.1136/bmj.39391.713229.AD

3. O'Sullivan BP, Freedman SD. Cystic fibrosis. Lancet Lond Engl 2009;373(9678):1891-904. https://doi.org/10.1016/S0140-6736(09)60327-5

4. Capurso G, Traini M, Piciucchi M, Signoretti M, Arcidiacono PG. Exocrine pancreatic insufficiency: prevalence, diagnosis, and management. Clin Exp Gastroenterol 2019;12:129-39. https://doi.org/10.2147/CEG.S168266

5. Somaraju UR, Solis-Moya A. Pancreatic enzyme replacement therapy for people with cystic fibrosis. Cochrane Database Syst Rev 2016;2016(11]. https://www.ncbi.nlm.nih.gov/pmc/ articles/PMC6734127/

https://doi.org/10.1002/14651858.CD008227.pub3

6. Sinaasappel M, Stern M, Littlewood J, Wolfe S, Steinkamp G, Heijerman HGM, et al. Nutrition in patients with cystic fibrosis: a European Consensus. J Cyst Fibros Off J Eur Cyst Fibros Soc 2002;1(2):51-75.

https://doi.org/10.1016/S1569-1993(02)00032-2

7. Ketwaroo GA, Graham DY. Rational Use of Pancreatic Enzymes for Pancreatic Insufficiency and Pancreatic Pain. Adv Exp Med Biol 2019;1148:323-43.

https://doi.org/10.1007/978-981-13-7709-9_14

8. Walkowiak J, Lisowska A, Blaszczyński M. The changing face of the exocrine pancreas in cystic fibrosis: pancreatic sufficiency, pancreatitis and genotype. Eur J Gastroenterol Hepatol 2008;20(3):157-60.

https://doi.org/10.1097/MEG.0b013e3282f36d16

9. Ooi CY, Dorfman R, Cipolli M, Gonska T, Castellani C, Keenan K, et al. Type of CFTR Mutation Determines Risk of Pancreatitis in Patients With Cystic Fibrosis. Gastroenterology 2011;140(1):153-61.

https://doi.org/10.1053/j.gastro.2010.09.046

10. Coffey MJ, Ooi CY. Pancreatitis in Cystic Fibrosis and CFTRRelated Disorder. Acute Pancreatitis. IntechOpen 2012.

https://www.intechopen.com/books/acute-pancreatitis/ pancreatitis-in-cystic-fibrosis-and-cftr-related-disorder

11. Gapp J, Chandra S. Acute Pancreatitis. StatPearls Publishing 2021. http://www.ncbi.nlm.nih.gov/books/NBK482468/

12. O'Shea D, O'Connell J. Cystic fibrosis related diabetes. Curr
Diab Rep 2014;14(8):511.

https://doi.org/10.1007/s11892-014-0511-3

13. Kayani K, Mohammed R, Mohiaddin H. Cystic Fibrosis-Related Diabetes. Front Endocrinol. 2018;9. https://www.ncbi.nlm.nih. gov/pmc/articles/PMC5826202/

https://doi.org/10.3389/fendo.2018.00020

14. Lewis C, Blackman SM, Nelson A, Oberdorfer E, Wells D, Dunitz J, et al. Diabetes-related Mortality in Adults with Cystic Fibrosis. Role of Genotype and Sex. Am J Respir Crit Care Med 2015;191(2):194-200.

https://doi.org/10.1164/rccm.201403-0576OC

15. Lee KMN, Miller RJH, Rosenberg FM, Kreisman SH. Evaluation of glucose tolerance in cystic fibrosis: comparison of 50 -g and 75-g tests. J Cyst Fibros Off J Eur Cyst Fibros Soc 2007;6(4):274-6. https://doi.org/10.1016/j.jcf.2006.10.008

16. Godbout A, Hammana I, Potvin S, Mainville D, Rakel A, Berthiaume Y, et al. No relationship between mean plasma glucose and glycated haemoglobin in patients with cystic fibrosis-related diabetes. Diabetes Metab 2008;34(6 Pt 1):568-73. https://doi.org/10.1016/j.diabet.2008.05.010

17. Moran A, Brunzell C, Cohen RC, Katz M, Marshall BC, Onady $\mathrm{G}$, et al. Clinical care guidelines for cystic fibrosis-related diabetes: a position statement of the American Diabetes Association and a clinical practice guideline of the Cystic Fibrosis Foundation, endorsed by the Pediatric Endocrine Society. Diabetes Care 2010;33(12):2697-708.

https://doi.org/10.2337/dc10-1768

18. Mainguy C, Bellon G, Delaup V, Ginoux T, Kassai-Koupai B, Mazur S, et al. Sensitivity and specificity of different methods for cystic fibrosis-related diabetes screening: is the oral glucose tolerance test still the standard? J Pediatr Endocrinol Metab JPEM 2017;30(1):27-35.

https://doi.org/10.1515/jpem-2016-0184

19. Brennan AL, Beynon J. Clinical updates in cystic fibrosis-related diabetes. Semin Respir Crit Care Med 2015;36(2):236-50. https://doi.org/10.1055/s-0035-1547319

20. Robinson NB, DiMango E. Prevalence of gastroesophageal reflux in cystic fibrosis and implications for lung disease. Ann Am Thorac Soc 2014;11(6):964-8.

https://doi.org/10.1513/AnnalsATS.201401-044FR

21. Pauwels A, Blondeau K, Mertens V, Farre R, Verbeke K, Dupont LJ, et al. Gastric emptying and different types of reflux in adult patients with cystic fibrosis. Aliment Pharmacol Ther 2011;34(7):799-807. https://doi.org/10.1111/j.1365-2036.2011.04786.x

22. Katz PO, Gerson LB, Vela MF. Guidelines for the Diagnosis and Management of Gastroesophageal Reflux Disease. Off J Am Coll Gastroenterol ACG 2013;108(3):308-28. https://doi.org/10.1038/ajg.2012.444

23. van der Doef HPJ, Arets HGM, Froeling SP, Westers P, Houwen 
RHJ. Gastric acid inhibition for fat malabsorption or gastroesophageal reflux disease in cystic fibrosis: longitudinal effect on bacterial colonization and pulmonary function. J Pediatr 2009; 155(5):629-33.

https://doi.org/10.1016/j.jpeds.2009.06.040

24. Seeras K, Bittar K, Siccardi MA. Nissen Fundoplication. StatPearls Publishing 2021. http://www.ncbi.nlm.nih.gov/books/ NBK519521/

25. Fathi H, Moon T, Donaldson J, Jackson W, Sedman P, Morice AH. Cough in adult cystic fibrosis: diagnosis and response to fundoplication. Cough Lond Engl 2009;5:1.

https://doi.org/10.1186/1745-9974-5-1

26. Ciro D, Padoan R, Blau H, Marostica A, Fuoti M, Volpi S, et al. Growth retardation and reduced growth hormone secretion in cystic fibrosis. Clinical observations from three CF centers. J Cyst Fibros 2013;12(2):165-9. https://doi.org/10.1016/j.jcf.2012.08.003

27. Brownell JN, Bashaw H, Stallings VA. Growth and Nutrition in Cystic Fibrosis. Semin Respir Crit Care Med 2019;40(6):77591.

https://doi.org/10.1055/s-0039-1696726

28. Lavi E, Gileles-Hillel A, Zangen D. Somatic growth in cystic fibrosis. Curr Opin Endocrinol Diabetes Obes 2020;27(1):38-46. https://doi.org/10.1097/MED.0000000000000522

29. Colombo C, Battezzati PM, Crosignani A, Morabito A, Costantini D, Padoan R, et al. Liver disease in cystic fibrosis: A prospective study on incidence, risk factors, and outcome. Hepatol Baltim Md 2002;36(6):1374-82.

https://doi.org/10.1002/hep.1840360613

30. Lamireau T, Monnereau S, Martin S, Marcotte J-E, Winnock M, Alvarez F. Epidemiology of liver disease in cystic fibrosis: a longitudinal study. J Hepatol 2004;41(6):920-5.

https://doi.org/10.1016/j.jhep.2004.08.006

31. Debray D, Kelly D, Houwen R, Strandvik B, Colombo C. Best practice guidance for the diagnosis and management of cystic fibrosis-associated liver disease. J Cyst Fibros Off J Eur Cyst Fibros Soc. 2011;10 Suppl 2:S29-36. https://doi.org/10.1016/S1569-1993(11)60006-4

32. Mendizabal M, Reddy KR, Cassuto J, Olthoff KM, Faust TW, Makar GA, et al. Liver transplantation in patients with cystic fibrosis: analysis of United Network for Organ Sharing data. Liver Transplant Off Publ Am Assoc Study Liver Dis Int Liver Transplant Soc 2011;17(3):243-50.

https://doi.org/10.1002/lt.22240

33. Miller MR, Sokol RJ, Narkewicz MR, Sontag MK. Pulmonary function in individuals who underwent liver transplantation: from the US cystic fibrosis foundation registry. Liver Transplant Off Publ Am Assoc Study Liver Dis Int Liver Transplant Soc 2012;18(5):585-93.

https://doi.org/10.1002/1t.23389

34. 2016 Patient Registry Annual Data Report. 2016;94.
35. McKnight CL, Burns B. Pneumothorax. StatPearls Publishing 2021. http:/www.ncbi.nlm.nih.gov/books/NBK441885/

36. Flume PA, Strange C, Ye X, Ebeling M, Hulsey T, Clark LL. Pneumothorax in cystic fibrosis. Chest 2005;128(2):720-8. https://doi.org/10.1378/chest.128.2.720

37. Flume PA. Pneumothorax in Cystic Fibrosis. CHEST 2003;123(1):217-21. https://doi.org/10.1378/chest.123.1.217

38. Alothman GA, Alsaadi MM, Ho BL, Ho SL, Dupuis A, Corey $\mathrm{M}$, et al. Evaluation of bronchial constriction in children with cystic fibrosis after inhaling two different preparations of tobramycin. Chest 2002;122(3):930-4. https://doi.org/10.1378/chest.122.3.930

39. Kioumis IP, Zarogoulidis K, Huang H, Li Q, Dryllis G, Pitsiou G, et al. Pneumothorax in cystic fibrosis. J Thorac Dis 2014;6(Suppl 4):S480-7.

40. Schramel FM, Postmus PE, Vanderschueren RG. Current aspects of spontaneous pneumothorax. Eur Respir J 1997;10(6):1372-9. https://doi.org/10.1183/09031936.97.10061372

41. de Moya MA, Seaver C, Spaniolas K, Inaba K, Nguyen M, Veltman Y, et al. Occult pneumothorax in trauma patients: development of an objective scoring system. J Trauma 2007;63(1):13-7.

https://doi.org/10.1097/TA.0b013e31806864fc

42. Flume PA, Mogayzel PJ, Robinson KA, Rosenblatt RL, Quittell L, Marshall BC, et al. Cystic fibrosis pulmonary guidelines: pulmonary complications: hemoptysis and pneumothorax. Am J Respir Crit Care Med 2010;182(3):298-306. https://doi.org/10.1164/rccm.201002-01570C

43. Ahmad AM. Essentials of Physiotherapy after Thoracic Surgery: What Physiotherapists Need to Know. A Narrative Review. Korean J Thorac Cardiovasc Surg. 2018;51(5):293-307. https://doi.org/10.5090/kjtcs.2018.51.5.293

44. Efrati O, Harash O, Rivlin J, Bibi H, Meir M-Z, Blau H, et al. Hemoptysis in Israeli CF patients--prevalence, treatment, and clinical characteristics. J Cyst Fibros Off J Eur Cyst Fibros Soc 2008;7(4):301-6. https://doi.org/10.1016/j.jcf.2007.11.007

45. Flume PA, Yankaskas JR, Ebeling M, Hulsey T, Clark LL. Massive hemoptysis in cystic fibrosis. Chest 2005;128(2):729-38. https://doi.org/10.1378/chest.128.2.729

46. Ittrich H, Bockhorn M, Klose H, Simon M. The Diagnosis and Treatment of Hemoptysis. Dtsch Ärztebl Int 2017;114(21):371-81. https://doi.org/10.3238/arztebl.2017.0371

47. Chun J-Y, Morgan R, Belli A-M. Radiological management of hemoptysis: a comprehensive review of diagnostic imaging and bronchial arterial embolization. Cardiovasc Intervent Radiol 2010;33(2):240-50. https://doi.org/10.1007/s00270-009-9788-z

48. Springer DM, Cofta S, Juszkat R, Żabicki B, Goździk-Spychalska J, Nowicka A, et al. The effectiveness of bronchial 
artery embolisation in patients with haemoptysis. Adv Respir Med 2018;86(5):220-6.

https://doi.org/10.5603/ARM.2018.0035

49. Pelluau S, Oualha M, Souilamas R, Hubert PH. [Respiratory failure in cystic fibrosis: management in pediatric intensive care unit, lung transplantation recommendation]. Arch Pediatr Organe Off Soc Francaise Pediatr 2012;19 Suppl 1:S40-43. https://doi.org/10.1016/S0929-693X(12)71109-0

\section{THE COMPLICATIONS OF CYSTIC FIBROSIS AND THEIR TREATMENT \\ P. Bajerčius}

Keywords: cystic fibrosis, complications, treatment.

Summary

Cystic fibrosis is a genetic disease caused by a mutation in the CFTR gene, in the 7th chromosome. The disease is transmitted through the autosomal recessive pathway, while a person with only one copy of the mutated gene is a carrier and usually healthy. People with cystic fibrosis possess secretions of higher viscosity, which cause obstructive pathologies in various organ systems. These changes can facilitate severe complications, which may drastically reduce both the lifespan and the quality of life for patients. Because of the systemic effect of the disease, cystic fibrosis requires multidisciplinary treatment, thus it is imperative to be able to diagnose and evaluate the various complications.

Aim: to analyze the complications of cystic fibrosis and their treatment.

Methods: the literature reviewed was found in the "Pubmed" database. Specific keywords such as cystic fibrosis, complica- tions, treatment, affected systems were used to find relevant information. A total of 150 articles were carefully reviewed and sifted accordingly to remove articles with indistinguishable information as well as abstracts and titles unrelated to the topic at hand. Either full articles or only their abstracts were analyzed with a final remaining count of 49 suitable articles. No time restriction was applied to citations.

Results: the most common systems to be damaged are the respiratory system, the gastrointestinal system, the renal system and the endocrine system. The main complications are growth disorders, pancreatic insufficiency, malabsorption, diabetes mellitus and various liver disorders due to bile duct and pancreas damage, and frequent lung complications and finally, respiratory failure due to lung damage. Respiratory failure is treated with artificial respiration. Terminal stages of the complications can be treated by organ transplantations.

Conclusions: Despite treatment efforts, organ damage progresses over time and many patients require organ transplantations in the terminal stages of the disease. Nevertheless, with adequate treatment it is possible to extend the lifespan of the patient. The Treatment of complications is also beneficial to the prevention of further complications.

Correspondence to: pauliusbajer@gmail.com

Gauta 2021-05-11 